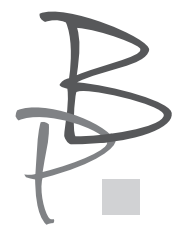

\author{
Halina Turkiewicz* \\ Vytautas Magnus University in Kaunas, Lietuva /
}

/ Akademia Edukacji w Wilnie Uniwersytetu Witolda Wielkiego w Kownie, Litwa

ORCID: 0000-0002-4368-7063

\title{
„Od nich przejąłem nazwy ptaków i owoców". Obraz domu i rodziny w poetyckim ujęciu Czesława Miłosza
}

"I took the names of birds and fruit from them". The Poetic Image of Home and Family Created by Czesław Miłosz

Abstract: The focus of the present article is on Czesław Miłoszz poetry in which the Nobel Prize winner returns to his childhood places and people who played a significant role in the formation of his personality and identity. The poet links specific sides of his personality with his birthplace, Szetejnie on the River Nevezis, located "in the heart of Lithuania". In his poetry, Miłosz devotes special attention to his mother, Weronika, from the Kunat family, and pays less attention to his father. He also remembers his grandfather Zygmunt Kunat, his wife Janina and other distant relatives. Miłosz creates the image of home and family through detailed poetic descriptions evoking at times episodes of a close relationship with his family members. Thus, the poet intends 
to express his appreciation for places that he is part of and gratitude to those who contributed to his existence in time, his formation and journey to eternity.

Keywords: Czesław Miłosz, home, family, childhood, Lithuania.

Temat artykułu brzmi może nieco banalnie, nadawałby się chyba raczej do szkicu eseistycznego. To jedna sprawa, która onieśmiela przed jego podjęciem. Druga sprawa: był już częściowo omawiany przez samego Miłosza, jeżeli powołać się chociażby na Dolinę Issy czy jego eseistykę, zwłaszcza Rodzinna Europę, lecz też Aleksandra Fiuta Autoportret przekorny, zawierający rozmowy z Czesławem Miłoszem, w których niemało miejsca zajmuje tak zwane dokopywanie się do korzeni, czyli zgłębianie roli przodków w ukształtowaniu takiego czy innego losu artysty. Rodzinny wątek w życiu Noblisty był też omawiany w rozmaitego typu kompendiach, z biografią Miłosz autorstwa Andrzeja Franaszka na czele.

Warto przypomnieć, że jeżeli chodzi o temat domu i rodziny, to bardzo podatnym materiałem do jego penetrowania jest, oczywiście, Dolina Issy. Monika Brzóstowicz w artykule Dom rodzinny w „Dolinie Issy”: obecność $i$ wartość słusznie zwraca uwagę na to, że obraz domu rodzinnego jest jednym z najbardziej istotnych składników całej twórczości Miłosza:

Wizerunek domu rodzinnego i kategoria rodzinności niewątpliwie należą do ważnych idei w twórczości autora Doliny Issy. Nie można wszak nie zauważyć powracających u Czesława Miłosza obrazów domu i refleksji nad związkami rodzinnymi, jak w cyklu Świat. (Poema naiwne), jak w wierszach Rodzina czy Nauki. Temat rodzinnego gniazda ma dla Miłosza znaczenie bardzo osobiste i wiąże się z „powrotem do własnych źródeł”, z „prehistorią” jego życia, z obrazami dzieciństwa i młodości na Litwie, które pojawiają się stale w twórczości tego autora ${ }^{1}$.

1 M. Brzóstowicz, Dom rodzinny w „Dolinie Issy”: obecność $i$ wartość, „Pamiętnik Literacki” 1997, z. 2, s. 13. 
Wagę tematu odnotowuje także Jerzy Jarzębski, który porównując stosunek do domu rodzinnego w twórczości Gombrowicza i Miłosza, pisze, że ostatni:

[...] całe życie niejako odbudowuje swój rodzinny dom - wcześnie utracony i ta rekonstrukcja może mieć wymiar albo dosłowny (jak w Świecie czy Dolinie Issy), albo metaforyczny - gdy pojęcie „rodziny” wchłania w siebie całe wspólne dla wielu nacji dziedzictwo kulturowe (wskażmy na symboliczny tytuł Rodzinnej Europy) $)^{2}$.

Zaskakujące wydaje się natomiast stwierdzenie wytrawnego znawcy twórczości Miłosza, Aleksandra Fiuta, który podejmuje polemikę z Jarzębskim:

„Rodzina jest dla niego centrum porządku świata”? Ależ obrazu rodziny w jego utworach właściwie nie ma! Owszem, wyjątek stanowi Świat. (Poema naiwne). Jest to jednak wizja świadomie wyidealizowana, pokazująca świat - a więc i dom taki, jakim powinien być, opatrzona ponadto znakiem zapytania³.

Następnie badacz powołuje się na kilka zaledwie tekstów poetyckich, w których w takiej czy innej odsłonie pojawia się obraz rodziny: List 1/I $1935 \mathrm{r}$, Świty, Rodzina, Myśl o Azji, Nauki. Podrozdział krótko omawiający te wiersze ma tytuł Wobec najbliższych. Przy takim ujęciu sprawy można, jak się wydaje, wskazać znacznie większą wiązkę tekstów, w których nie mówi się bezpośrednio o znaczeniu rodziny, lecz poświęca się czasem osobne wiersze poszczególnym jej przedstawicielom. To zrozumiałe, że autor całościowej monografii o poezji Miłosza musiał poddać materiał bardzo surowej selekcji i nie miał możliwości powoływania się na wszystkie teksty, w których w taki czy inny sposób pojawia się konterfekt kogoś z rodziny poety.

Co zatem nowego może dorzucić do tematu niniejszy artykuł? Powiedzmy od razu, że jego celem jest spojrzenie na obraz domu i rodziny głównie przez pryzmat poezji Miłosza, gdyż właśnie ten zrąb twórczości uznał artysta, podobnie jak jego mistrz Jarosław Iwaszkiewicz, za najważniejszą część swojego dorobku.

2 J. Jarzębski, Gra w Gombrowicza, Warszawa 1982, s. 376.

3 A. Fiut, Moment wieczny. Poezja Czesława Miłosza, Kraków 2011, s. 176-177. 
Obraz domu w poezji Miłosza był już częściowo przeze mnie omawiany w artykule poświęconym „małej ojczyźnie” twórcy4. Miłosz, jak wiadomo, wędrując przez państwa i kontynenty, miał niejeden dom w swoim życiu, jednakże za epicentrum uważał położone „w samym sercu Litwy” Szetejnie nad Niewiażą. W swoim późnym wierszu $W$ Szetejniach zaakcentował to wyraziście i jednoznacznie: „Gdziekolwiek wędrowałem, po jakich kontynentach, zawsze twarzą byłem zwrócony do Rzeki”'5.

Kiedy zachodziła potrzeba wyeksponowania esencji domu i rodziny, wracał do przestrzeni dzieciństwa, do miejsc i osób, które towarzyszyły mu od zarania, od tego momentu, kiedy nie mógł jeszcze analizować swoich gestów i odruchów, kiedy był zdany na łaskę innych. Patrząc z perspektywy niespokojnego XX wieku, dobitnie uświadamiał, jak wiele zależy od okoliczności przestrzennych, historycznych, rodzinnych przyjścia na świat, jak niewiele, a w niemowlęcym okresie właściwie nic, nie zależy od woli samego człowieka:

Od tamtej chwili, kiedy w domu o niskich okapach

Doktor z miasteczka przeciął pępowinę,

A pleniły się w sadach szczawie i lebiody,

Gniazda dla kropkowanych białą pleśnią gruszek,

Byłem już w rękach ludzi. Mogli przecie zdławić

Mój krzyk pierwszy, nacisnąć swoją wielką dłonią

Gardło bezbronne, budzące ich czułość.

Od nich przejąłem nazwy ptaków i owoców,

W ich kraju zamieszkałem, nie zanadto dzikim,

Nie zanadto uprawnym, z łąką, ornym polem

I wodą na dnie czółna w gąszczu za stolarnią ${ }^{6}$.

Powołując się na ten wiersz, Aleksander Fiut pisał:

4 H. Turkiewicz, ,, Krajobrazy i być może duchy Litwy nigdy mnie nie opuścity.” Wyznaczniki „,małej ojczyzny” w poezji Czestawa Mitosza, [w:] Pogranicza, cezury, zmierzchy Czestawa Miło$s z a$, red. A. Janicka, K. Korotkich, J. Ławski, Białystok 2011, s. 31-49.

5 Cz. Miłosz, Wiersze wszystkie, Kraków 2011, s. 1110.

6 Tamże, s. 467. 
Nawet w autobiograficznych Naukach dom jest niejako „podminowany” przez rozmaite zagrożenia. Powiada poeta, że od urodzenia był „w rękach ludzi”, którzy kształtowali jego przyzwyczajenia, system ocen, obyczaje i mowę. Ale - dodaje zaraz - „Mogli przecie zdławić / Mój krzyk pierwszy [...] Niebezpieczeństwo nie wynika jedynie z możliwości śmierci; równie istotne jest ciśnienie przeszłości. Za wspólnotę ze swoją własną czy też całą ludzką rodziną człowiek płaci wysoką cenę, dziedziczy w rozumieniu genetycznym i kulturowym. Musi uporać się z kłopotliwym spadkiem fizycznych i umysłowych ułomności swoich przodków, nawet dalekich i nieznanych (co w wierszu sygnalizują archaiczne formy imion krewnych), a zarazem - na własną rękę podjąć dialog z indywidualną i zbiorową przeszłością historyczną ${ }^{7}$.

Tę wielką zależność od przestrzeni dzieciństwa potwierdził też Franaszek, który rozdział poświęcony Szetejniom nieprzypadkowo zatytułował za Miłoszem Raj ziemski i napisał w nim między innymi:

[...] Szetejnie, a nie żadne z wileńskich, warszawskich, francuskich, kalifornijskich mieszkań, stały mu się domem w najpełniejszym znaczeniu tego słowa, pozostały w pamięci jako oś świata, własne miejsce na ziemi ${ }^{8}$.

Podobnie ma się sprawa z osobami, które najwybitniej zaważyły na kształtowaniu się natury przyszłego poety. Mają one także najczęściej związek z Szetejniami i okolicą. Oddajmy ponownie głos Franaszkowi, który, wnikając w twórczość Miłosza, jak też w różnego rodzaju teksty paraliterackie, pisze:

„Wyobraźnia moja, sięgając wstecz, najbardziej zabarwiała się uczuciowo, kiedy uznawałem powagę matriarchatu. Kobiety były zrobione z najmocniejszej tkaniny" (RE, 78) - wyznawał Czesław Miłosz, i rzeczywiście w jego wspomnieniach widać, że kluczowymi postaciami były dlań w dzieciństwie kobiety: matka, a zaraz potem babcia Józefa Syruć, swą nietuzinkową osobowością ogniskująca zainteresowanie chłopca. Nieco dalej znajdowałaby się babka Stanisława i dziadek Kunat, najbardziej zaś peryferyjnie - ojciec. Emocjonalny pejzaż ulegnie zmianie, gdy

8 A. Franaszek, Miłosz. Biografia, Kraków 2011, s. 31. 
rodzina zamieszka w Wilnie, zaś obok różnic między bliską, ciepłą, ale też mocną matką i dalekim słabym ojcem równie ważna jest opozycja inna, wyznaczająca bieguny osobowości poety. Sam nazwie to dwoma rodzajami krwi: oto gęsta, zdrowa, trzeźwa, pracowita krew Syruciów i Kunatów (a kunas to po litewsku "ciało") miesza się z rozwodnioną, słabą, chimeryczną, skłonną do umysłowych ekstrawagancji, depresji, a nawet chorób psychicznych krwią Miłoszów, tworząc złożony konglomerat, który określi przyszłego autora Ocalenia?.

Dorobek poetycki Miłosza potwierdza w znacznym stopniu zasadność tych spostrzeżeń. Nawet bez obliczeń statystycznych można dostrzec, że jeżeli chodzi o poetyckie konterfekty swojej rodziny, to palma pierwszeństwa zdecydowanie przypada tu matce. $Z$ rozrzuconych po całej poezji Miłosza wierszy o matce czy też krótkich o niej wzmianek w poszczególnych utworach można byłoby zbudować portret fizyczny i duchowy Weroniki z Kunatów Miłoszowej. Wizerunkowi matki poświęcił też Miłosz obszerne partie między innymi w Dolinie Issy, Rodzinnej Europie, rozmowach z Aleksandrem Fiutem.

W Rodzinnej Europie wyeksponował zauważone przez siebie tkwiące jakoby w matce sprzeczności. Z jednej strony, „zdawałoby się lekkomyślna i słaba", z innej, jak syn zauważył:

Pod powierzchnią krył się upór, powaga i mocne przekonanie, że cierpienia, jakie na nas spadają, są nam przeznaczone przez Boga i że należy je znosić pogodnie. Jeszcze jedną jej cechą był patriotyzm, nie zwracający się ku narodowi czy państwu - do tej jego odmiany odnosiła się powściągliwie. Wszczepiała mi natomiast patriotyzm „domu”, tj. rodzinnej prowincji. Przechylałem się wyraźnie ku rodzinie matki, ku dziadkowi Kunatowi i babce urodzonej Syruć10.

Spróbujmy odtworzyć wizerunek matki, posługując się obrazami, jakie zostały wpisane w poezję. Dla porządku przypomnijmy, że Weronika Tekla Kunat urodziła się w 1887 roku w rodzinie o szlacheckim rodowodzie. Była córką pochodzącego z Krasnogrudy Zygmunta Kunata i mającej litewskie korzenie Józefy z Syruciów. O rozpowszechnionej na Żmudzi litewskiej gałęzi

10 Cz. Miłosz, Rodzinna Europa, Kraków 1994, s. 64. 
Syruciów piszą między innymi Viktorija Daujotytė i Mindaugas Kvietkauskas, autorzy monografii Česlovo Milošo lietuviškieji kontekstai ${ }^{11}$.

Wędrując chronologicznie przez ocean poezji Miłosza, zatrzymajmy się przy istotnym dla naszego tematu poemacie Świat. To nietypowe dla całości dorobku poetyckiego dzieło, niejednokrotnie omawiane, interpretowane, podziwiane, ma, jak wiadomo, charakter uniwersalny. Jest to swego rodzaju hołd złożony „normalności” w czasie, kiedy jej zabrakło, kiedy świat ogarnęła trwoga, wywołana przez drugą wojnę światową. W czasie grozy i zamętu, w okresie, kiedy rzeczywistość podrzuca obrazy różnego rodzaju militariów, Miłosz znajduje panaceum duchowe, przypominając sobie i innym, jak powinien wyglądać świat. Budzi zarazem nadzieję, że normalność kiedyś wróci, że trwoga minie. Jak wynika z owego poematu czy też cyklu wierszy, prawdziwe, bezpieczne zaplecze powinien stanowić dom, skupiona w nim rodzina, jej praca, nauka, zgodne wysiłki w poznawaniu, upiększaniu, udoskonalaniu świata. Nieprzypadkowo na pierwszym planie wyeksponowane są obrazy ojca, matki i dzieci. Niejednokrotnie zostało już dowiedzione, że tworząc ten uniwersalny obraz domu i rodziny, Miłosz w wielkim stopniu czerpał szczegóły z przestrzeni swojego dzieciństwa w Szetejniach. Dotyczy to także obrazu matki, która pojawia się w wierszu Jadalnia. Matka występuje tu w swojej odwiecznej roli jako żywicielka, karmicielka rodziny. Po przywołaniu wiele zawdzięczającego dworowi w Szetejniach wyposażenia jadalni poeta wprowadza matkę, zajmującą się charakterystycznym dla niej codziennym rytuałem:

Tuż drugi zegar. Ptak wewnątrz tam siedzi,

Wybiega skrzypiąc i woła trzy razy.

A ledwo zdąży krzyknąć po raz trzeci,

Dymiącą zupę matka bierze z wazy.

Z kolei w następującym po Jadalni wierszu Schody matka i dosłownie, i przenośnie jest nosicielką światła, strażniczką ogniska domowego. Obraz matki jest już kreowany wyraźnie z myślą o realnej rodzicielce, co widać na

11 V. Daujotytė, M. Kvietkauskas, Lietuviškieji Česlovo Milošo kontekstai, Lietuvių literatūros ir tautosakos institutas, Vilnius 2011, s. 66. 
podstawie takich szczegółów opisu, jak wygląd, elementy ubioru oraz znamienne rysy charakteru:

Matka w dół płomień migotliwy niesie.

Schodzi wysoka, sznurem przepasana.

Jej cień do cienia dziczej głowy pnie się:

Tak z groźnym zwierzem mocuje się sama ${ }^{12}$.

Nie jest też pozbawiony konkretów obraz trzeci, w którym również występuje matka. Tym razem umiejscowiona jest Przy piwoniach (kwiaty te rosły obficie przy dworze w Szetejniach), wtajemnicza dzieci w świat natury:

Matka nad klombem z piwoniami staje,

Sięga po jedną i płatki rozchyla,

I długo patrzy w piwoniowe kraje,

Dla których rokiem bywa jedna chwila.

Potem kwiat puszcza i, co sama myśli,

Głośno i dzieciom, i sobie powtarza.

A wiatr kołysze zielonymi liśćmi

I cętki światła biegają po twarzach ${ }^{13}$.

Kolejną okazją do złożenia hołdu matce stała się jej przedwczesna śmierć w 1945 roku. Okoliczności śmierci Weroniki Kunat opisze Miłosz po latach, dodając komentarz do swojego kolejnego wiersza o matce, zatytułowanego Z nia (1985) i umieszczonego w zbiorku Kroniki. Przywołajmy ten komentarz, gdyż stanowi on pośrednią charakterystykę zalet duchowych, jakimi była obdarzona matka Miłosza:

W roku 1945, podczas wielkich przesiedleń ludności przy końcu drugiej wojny światowej, moja rodzina opuściła Litwę i znalazła się w okolicach Gdańska, gdzie zakwaterowano ją w domu należącym do niemieckiej chłopskiej rodziny. W domu została tylko jedna stara Niemka, która właśnie zachorowała na tyfus i nie miała

12 Cz. Miłosz, Wiersze wszystkie, s. 197.

13 Tamże, s. 201. 
nikogo, kto by się nią zajął. Moja matka, wbrew perswazjom, pielęgnowała ją, zaraziła się tyfusem i umarła ${ }^{14}$.

W wierszu Grób matki, napisanym w 1949 roku, poeta daje upust głębszym refleksjom filozoficznym. Wracając myślami do Sopotu, gdzie spoczęły doczesne szczątki „tej, co mnie zrodziła”, jak ujmuje poeta, prowadzi on rozmowę z ukochaną rodzicielką. Poddaje tu gorzkiej refleksji okrutne prawo przemijania, które nurtowało go przez całe świadome życie:

[...] Czemu tak jest, matko,

Że ani ranek, ani kwiat ni śniade

Jabłko na szorstkiej gałęzi jabłoni

Nie potrwa dłużej niż to jedno mgnienie?

Czemu otwiera się skrzydło motyla

Na lot mierzony ziarnkami klepsydry

I czemu matko sama być przestajesz

Piękną dziewczyną w której się kochałem? [...] ${ }^{15}$

Wiersz zwieńczony jest charakterystyczną w utworach elegijnych puentą-podziękowaniem:

Żeś chciała życia udzielić mi daru

Bądź pozdrowiona w imię Boga. Amen ${ }^{16}$.

Zamykające utwór końcowe „amen” nie oznacza bynajmniej zamknięcia tematu matki w poezji Miłosza. Wręcz przeciwnie. Można odnieść wrażenie, że w miarę dojrzewania, w miarę oddalania się czasowego i przestrzennego od ziemi dzieciństwa wspomnienia coraz mocniej atakują pamięć poety, który przy różnych okazjach, w różnych kontekstach wskrzesza takie czy inne epizody obcowania ze swoimi bliskimi i, w pierwszej kolejności, z matką.

14 Tamże, s. 963.

15 Tamże, s. 280.

16 Tamże, s. 282. 
Zarówno realna ziemska matka, jak i samo słowo „matka” stanowią dla Miłosza sferę sacrum. W wierszu Strukturalizm, w którym poeta, komentując wykład strukturalisty (niczym Mickiewicz w Romantyczności sprzeciwiający się „mędrca szkiełku i oku”), medytuje nad swoją śmiesznością w dobie bezdusznej cywilizacji komputerów i przywołuje jeden z charakterystycznych przykładów swojej inności, nieporadności, dziwaczności:

Ja śmieszny, tak samo jak wtedy, kiedy byłem mały i próbowałem bronić świętych gajów czy góry Synaj czy Patmos, nie rozumiejąc czego bronię i czemu. Bo dzieci podskakiwały i rymowały wyrazy i jeden chłopczyk śpiewał: „matka-szmatka, matka szmatka", a ja nagle rzuciłem się na niego, kopiąc i gryzą ${ }^{17}$.

Nie jest to epizod fikcyjny. Ma swoją wersję również w prozie, zostaje przywołany w powieści Dolina Issy.

Miłoszowskie dążenie, jeżeli zastosować może nieco wytartą przez nadużywanie kategorię, „do formy bardziej pojemnej” i gorliwość w rejestrowaniu konkretu i szczegółu prowadziły niejednokrotnie do przeplatania poezji wtrętami paraliterackimi, eseistycznymi. Niezwykle przydatne okazały się one przy utrwalaniu pamięci o swoich przodkach, w tym i o matce. Za swoiste faktograficzne wprowadzenie do portretu matki można uznać komentarze rozsiane w poszczególnych fragmentach hybrydycznego poematu Gdzie wschodzi stońce $i$ kędy zapada. W encyklopedycznych niemal inkrustacjach do tego poematu utrwala w jego części III. Lauda to, co już znamy z jego wcześniejszej eseistyki, między innymi z Rodzinnej Europy:

Moja matka urodziła się tam gdzie i jej matka i gdzie ja miałem się urodzić, we Dworze Szetejnie, czyli Šeteiniai na lewym brzegu Niewiaży, o 3 km od Świętobrości, czyli Šventybrastis, tuż przy Laudzie, jako córka Zygmunta Kunata [...] i Józefy z Syruciów ${ }^{18}$.

Wzmianka o Szetejniach jest tu niezwykle istotna, bo urodzenie się w takim, a nie innym miejscu, zakłada fundament pod przyszłą osobowość.

17 Tamże, Wiersze wszystkie, s. 547.

18 Tamże, s. 647. 
Wskrzeszając w pamięci różne epizody ze swojej prywatnej przestrzeni dzieciństwa, która zostaje potraktowana jako „Pathmos albo Lethe, Arcadia albo Parnassus", poeta nie omieszka przywołać wydarzenia opisanego już wcześniej w Dolinie Issy:

Bez ustanku zdumiony dniem moich narodzin, raz tylko jeden od początku do końca czasu.

Z lekkomyślnej kobiety, która jest jedno ze mną, litość nad nią śnię, stary człowiek.

Jej śmieszne suknie, jej tańce, tak przepadłe a znowu tak blisko.

I nazwać ją innym imieniem niż dawniej, dziecinnie jedynym Jest to i siebie samego zmierzyć, zapomnieć, policzyć. [...] Przez jakie spalone łąki biegnie ona ze mną na rękach Żeby od zębów zwierza synka obronić?

Zatrzaśnięta jest moja pamięć, kim byłem nie wiem na jawie.

Czy wypełniłem cokolwiek, czy usłużyłem komu.

I ona, mnie Ostrobramskiej Pannie ofiarująca Jak i dlaczego wysłuchana została? ${ }^{19}$

Przywoływanym epizodom dzieciństwa towarzyszą zazwyczaj jakieś ogólniejsze refleksje, jak chociażby pytanie, ,jak i dlaczego wysłuchana została?”, które jest już próbą wdzierania się w transcendencję.

Epizod ucieczki od psa jest przywołaniem tego, czego doświadczyło się bezpośrednio, co jest głęboko wyryte w pamięci, co znowuż uwypukla rolę matki, której misja nie kończy się na udzieleniu dziecku „daru życia”, lecz jest kontynuowana jako chronienie tego życia, przekazywanie niezbędnych wtajemniczeń, stałe czuwanie niezależnie od wieku latorośli.

W miarę upływu lat poeta próbuje sięgnąć głębiej do studni pamięci, przywołując wydarzenia, które poprzedziły jego narodziny. Wertując zbiorek Kroniki (1987), w którym dzieje prywatne, podobnie jak w Rodzinnej Europie, są skonfrontowane $\mathrm{z}$ wydarzeniami składającymi się na wielką historię, znajdujemy charakterystyczny pod tym względem wiersz Rok 1911. Zawiera on epizody dotyczące prehistorii narodzin poety, migawki zawdzięczane zdję- 
ciom bądź opowieściom rodzinnym, w których matka nie jest jeszcze matką. Odwiedza czasem leżące za rzeką Kałnoberże:

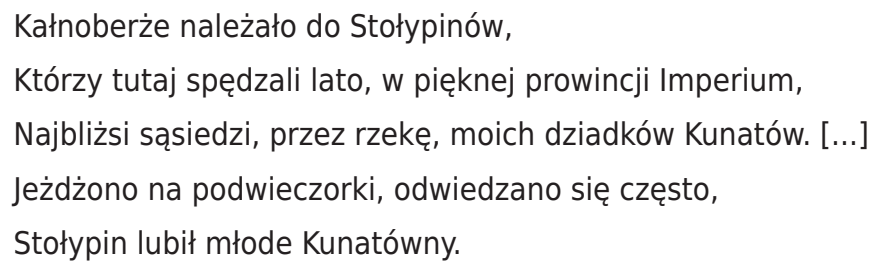

Poprawne, dobrosąsiedzkie stosunki nie oznaczały jednak zniesienia dystansu wobec przedstawiciela władzy Imperium, bo w tymże tekście zarysowane jest także inne oblicze przyszłej jeszcze wtedy matki poety:

Nie miała z tym nic do czynienia szkoła, jaką we dworze Założyła dla chłopskich dzieci Wercia, czyli Wecia, Późniejsza moja matka. Uczyła czytać i pisać. W jakim języku? Polskim oczywiście.

A więc Weronika Kunat jako nauczycielka, wtajemniczająca litewską młodzież w arkana języka polskiego, niczym „siłaczka” rozniecająca „kaganek oświaty" wśród chłopskich dzieci, układająca jednocześnie też swoje życie osobiste:

\author{
W 1909 roku \\ Wecia poślubiła studenta Politechniki Ryskiej. \\ W 1911 przyjechała do Szetejń, żeby mnie urodzić20.
}

Życie wymaga od Weroniki Miłoszowej coraz większych wyzwań. Dzieląc los męża, inżyniera budowy dróg i mostów, przemierza z małym dzieckiem ogromne połacie Rosji, co poeta utrwalił w kolejnych wierszach Kronik, takich jak Le Transsibérien czy Za Uralem (1913). W tym drugim zostały uwiecznione nawet jakieś migawki podróży pociągiem, w których poddane są refleksji kolejne rysy silnej, otwartej i mającej swoje ograniczenia osobowości matki:

20 Tamże, s. 938. 
[...] Samowar szumi od rana. Kupcy w swoim coupe

Piją czaj z drewnianych malowanych czarek.

Archeolog Wałujew opowiada mojej matce o wykopaliskach w Mongolii,

Po czym wdaje się w nieodmienny spór z Petersonem

Za trudny dla niej, choć była na pensji

I słuchała wykładów Zdziechowskiego w Krakowie.

Kolejna całostka dłuższego tekstu przywołuje epizody z ryskiego okresu, które uwieczniają aurę pierwszych lat po zamążpójściu i ukazują Weronikę jako pełnokrwistą osobę, niestroniącą od zabaw, tańców, od czerpania radości z życia:

\author{
Bursze, Arkoni i Weleci, \\ W mieście Ryga korowodem o północy. \\ Z nimi piękna mamusia, bo lubiła knajpowanie, \\ Choć była w ciąży ze mną - może się na mnie odbiło? ${ }^{21}$
}

W tym samym zbiorku znajdujemy także wspominany już wiersz $Z$ nia (1985), który można potraktować jako podwójnie okolicznościowy. Po pierwsze, jak dowiadujemy się z samego tekstu, poeta przypomina matkę, obchodząc swój „dzień [...] siedemdziesiątych czwartych urodzin”. Po drugie, jak wskazuje data pod tytułem, wiersz powstał czterdzieści lat po śmierci rodzicielki. Jeżeli wcześniejszy Grób matki był głównie ubolewaniem nad przemijaniem piękna, to teraz poeta wyeksponował motywy bólu, brzydoty, agonii. Sam doznając objawów starości, solidaryzuje się z matką w przyjmowaniu cierpienia i nawet z jej interpretacją życia: ,Wydaje mi się, że to wszystko było tylko snem" (s. 963) oraz nadzieją na zmartwychwstanie:

Te biedne, artretycznie spuchnięte kolana

Mojej mamusi w nieobecnym kraju.

Myślę o nich w dzień moich siedemdziesiątych czwartych urodzin,

Słuchając wczesnej mszy u Mary Magdalen w Berkeley.

Czytanie tej niedzieli z Księgi Mądrości, 
O tym, że Bóg nie uczynił śmierci

I nie raduje się zagładą żywych.

Czytanie z Ewangelii według Marka:

O dzieweczce, do której rzekł: „Talitha, kum!”.

To dla mnie. Żebym z martwych wstawał

I powtarzał nadzieję żyjących przede mną,

W przeraźliwej jedności z nią, z jej agonią

W wiosce pod Gdańskiem, w ciemnym listopadzie 22

Dodajmy jeszcze istotne spostrzeżenie, które w odniesieniu do tego tekstu sformułował Jarosław Ławski:

Jedność, o czym nie wolno zapomnieć, którą ustanawia syn z matką poprzez obrzęd, pamięć i słowo, jest „przeraźliwa”. Koło się zamyka. Niedoskonałość tryumfująca znosi chwilowe zwycięstwo miłości i tęsknoty. Jakkolwiek i to brzmi „sentymentalnie”: miłość i tęsknota, ale czy naprawdę są one, miłość i tęsknota, tylko „sentymentalne"? One są. Także u Miłosza: czyste, realne ${ }^{23}$.

Kolejną okazją do zintensyfikowania wspomnień o matce (i nie tylko o niej) stał się powrót Miłosza na Litwę w 1992 roku, po 52 latach nieobecności. Na trasie odbywanej wśród licznego grona obserwatorów podróży nie mogło zabraknąć, oczywiście, Szetejń. Poetyckie pokłosie owej wizyty znalazło miejsce w tomiku o wymownym tytule $\mathrm{Na}$ brzegu Rzeki. Zamyka go wiersz W Szetejniach, w którym obok przywołania zapamiętanych krajobrazów małej ojczyzny, konfrontowanych ze spustoszeniami, rażącymi wzrok poety po ponad pół wieku nieobecności, sporo miejsca zajmuje wskrzeszanie wspomnień o matce. Wiersz zaczyna się zresztą od apostrofy do niej:

Ty byłaś mój początek i znów jestem z Tobą, tutaj gdzie nauczyłem się czterech stron świata. [...]

W zdziczałej zieleni mógłbym wskazać miejsce altany, gdzie zmuszałaś mnie, żebym stawiał pierwsze koślawe litery.

22 Tamże, s. 963.

23 J. Ławski, Miłosz: „Kroniki” istnienia. Sylwy, Białystok 2014, s. 49. 
A ja wyrywałem się uciekając do moich kryjówek, bo byłem pewny, że pisać liter nigdy nie będę umiał ${ }^{24}$.

Druga część utworu przywołuje znacznie przyjemniejsze, związane z matką wspomnienia:

Trzymałaś lejce i dwoje nas jechało jednokonną bryczką w gościnę do wielkiej wioski pod lasem.

Gałęzie jej jabłoni i grusz ugięte pod nadmiarem owoców, ganki domów, ozdobne, nad ogródkami malw i ruty.

Twoi dawni uczniowie, teraz gospodarze, podejmowali nas rozmową o urodzajach, kobiety pokazywały swoje warsztaty tkackie i deliberowałyście długo o kolorach osnowy i odetki.

Na stole wędliny, plastry miodu w glinianej misie, i piłem kwas chlebowy z blaszanej kwarty 25 .

Barwne obrazy przeszłości przesłania smutna teraźniejszość: „pola puste aż po las" i brutalnie brzmiące słowa jakiegoś wtedy jeszcze kierownika kołchozu: „Tu była wioska Peiksva”. Część trzecia przekształca się w refleksję autotematyczną, w której znowu istotny byłby głos matki, gdyby można było go usłyszeć:

Teraz myślę, że dzieło jest zamiast szczęścia i że zostaje skażone litością i grozą.

Jednak duch tego miejsca musi być w nim, tak jak jest w Tobie, którą prowadził od dziecka.

Girlandy z dębowych liści, sygnaturka w rozwidleniu lipy wzywająca na Majowe, chciałem być dobry i nie chodzić między grzesznikami. [...]

Ty jedna, mądra i sprawiedliwa, umiałabyś mnie uspokoić, tłumacząc, że zrobiłem tyle, ile mogłem.

I to w zasadzie ostatni w dorobku Miłosza wiersz, w którym miejsce urodzenia identyfikuje się głównie z matką. W przypadających na początek 
XXI wieku zbiorkach - To, Druga przestrzeń, Wiersze ostatnie obiektyw poety został bardziej skierowany na roztrząsanie własnego doświadczenia starości, elegijne pożegnanie ze światem, metafizyczne dociekania na temat ,jak powinno być w niebie".

Po przybliżeniu obrazu matki logiczne byłoby pytanie: jak wygląda postać ojca w poezji Miłosza? Już od razu można stwierdzić, że ojciec był dla poety znacznie mniejszym autorytetem niż matka. Wystarczy powołać się na bezpośrednie zwierzenia Miłosza z rozmów z Aleksandrem Fiutem ${ }^{26}$ czy znowuż spostrzeżenia wynikające $\mathrm{z}$ badań Franaszka, wspominanego już tutaj biografa Miłosza. Porządkując fakty dotyczące ojca Noblisty, Franaszek odnotowuje:

Urodzony w Rydze w 1883 roku Aleksander Aleksy Miłosz był spadkobiercą pokoleń szlacheckich przodków, którzy pozostawili mu piękne tradycje i herb Lubicz, ale nie majątek. Miłoszowie mieszkali na Litwie przynajmniej od XVI wieku, skoro czasów młodości poety doczekała umowa podpisana przez jednego z nich w roku 1578. Rodową siedzibą były Serbiny pod Wędziagołą, niedaleko Szetejń, być może pozostałość dużego kompleksu Łabunowo.

[...] Absolwent wileńskiego gimnazjum realnego, wielbiciel Gogola, nazywany w rodzinie Psiapsiulewiczem, co budzi skojarzenia tyleż niejasne, co niezbyt poważne, miał rozwinięte poczucie humoru, uwielbiał - opowiadane zresztą najczęściej po rosyjsku - dowcipy, świetnie śpiewał i tańczył, będąc tak zwaną duszą towarzystwa; a więc przejawiając dokładnie te zalety, których nigdy nie miał i nie poważał jego pierworodny ${ }^{27}$.

Obrazy obojga rodziców wyeksponowane są, jak wiadomo, w poemacie Świat. O ile jednak w występującym tutaj obrazie matki można doszukać się chociażby szczątkowych rysów Weroniki Miłoszowej, o tyle obraz ojca został skonstruowany bardzo uniwersalnie, rodzic występuje jako „wsparty na motyce” albo „w bibliotece” jako wtajemniczający dzieci w świat intelektualny, w sztukę czytania mistrz i czarodziej, jako wyprowadzający je w dalszy świat, otwierający europejską perspektywę spojrzenia, jako chroniący od trwogi wreszcie.

26 A. Fiut, ,,Autoportret przekorny”. Rozmowy z Czesławem Miłoszem, Kraków 2003.

27 A. Franaszek, Miłosz..., s. 37-38. 
Dopiero w poemacie Gdzie wschodzi stońce i kędy zapada, w jego części III. Lauda, znajdujemy krótką wzmiankę: „Mój ojciec urodził się w Serbinach pod Wędziagołą jako syn Artura Miłosza i Stanisławy z Łopacińskich”28. Wiersz Rok 1911 zawiera lakoniczną informację o tym, że „Wecia poślubiła studenta Politechniki Ryskiej”. W utworze Le Transsibérien wspomina się o jednej z największych pasji ojca, jaką było polowanie:

\author{
Koleją transsyberyjską jechałem do Krasnojarska \\ Z nianią Litwinką, z mamusią, dwuletni kosmopolita, \\ Uczestnik przyobiecanej europejskiej ery. \\ Tatuś polował na marale w Sajańskich Górach. \\ Ela i Nina biegały po plaży w Biarritz ${ }^{29}$.
}

Myśliwskie pasje ojca przyczyniły się zapewne do stworzenia bardzo plastycznych opisów polowań w Dolinie Issy, były też przywoływane na kartach Rodzinnej Europy, ukazujących także inne, niemałoważne zalety rodzica:

Mój ojciec nie miał żadnej zdolności do kariery ani do robienia pieniędzy, to jest brak mu było broni potrzebnej do walki z ludźmi, poza tym wszelka intryga i nawet taktyka, stosowana, żeby osiągnąć osobiste cele, wydawała mu się czymś nieszlachetnym. Jeżeli natrafiał na podstęp i chytrość, po prostu wyłączał się z gry i szukał pracy gdzie indziej. Natomiast walka z przeciwnościami natury podniecała go i upajała, bo była przygodą. Wychował się na niezwykle popularnych w Cesarstwie książkach Maynea Reida i Marryata. Dzika Syberia w niczym nie ustępowała Alasce i północy Kanady, przystrajała się dla niego w powab romantyczny. Nie troszczył się o zarobek, ale o używanie życia - co streszczało się w obliczeniach konstrukcji mostów i w jak najdalszych wędrówkach, jak choćby rzeką Jenisej, następnie zaprzęgami renów i psów do ujścia tej olbrzymiej rzeki do Oceanu. Dołączała się do tego namiętność myśliwska. Był dobrym strzelcem i nie mógł tu się uskarżać na brak terenów. W Górach Sajańskich polował na jelenie, na dzikie gęsi w tundrze za kołem polarnym. Przeżywał swój sen o eksploracji. Syberia, która pochłonęła kiedyś tylu naszych krewnych, nie była dla niego ziemią 
wygnania. W grubych zeszytach oprawnych w czarną ceratę wpisywał wierszehymny na cześć tamtejszej przyrody. Miał pewne zainteresowania literackie ${ }^{30}$.

Jeżeli matce Miłosz poświęca osobne wiersze, w których eksponuje w pierwszej kolejności jej zalety, to w przypadku ojca (przynajmniej w poezji) ogranicza się zazwyczaj do krótkich wzmianek, przywołania jakichś zapamiętanych faktów, nie podejmuje raczej próby ich wartościowania. Świadczy o tym cytowany już utwór Le Transsibérien, nie stroni od takiej postawy także wiersz Trytony (1913-1923), powstały wskutek wpatrywania się w fotografię z dawnej epoki i chęci utrwalenia, przekształcenia w „moment wieczny”, jak często u Miłosza, tego, „czego już nie ma”:

Poznaję ich. Stoją na pokładzie

Statku "Correct”, kiedy wpłynął w ujście Jeniseju.

Ten czarniawy, w skórzanej kurtce automobilisty

To Loris-Mielikow, dyplomata. Ten gruby, Wostrotin,

Właściciel kopalni złota i poseł do Dumy.

Obok szczupły blondyn, mój ojciec. I kościsty Nansen.

W wierszu zderzone zostają ze sobą trzy płaszczyzny przestrzenno-czasowe: rok 1913, w którym ojciec odbył utrwaloną na fotografii wyprawę, początek lat 20. w Wilnie, kiedy syn przygląda się tej fotografii, oraz „kalifornijska wiosna", czas napisania wiersza:

Fotografia wisi u nas w domu w Wilnie

Przy ulicy Podgórna 5. Obok słojów,

W których hoduję trytony. [...]

Mój ojciec, sprzed. Nie wiem, po co jeździł

Latem 1913 roku w ponure pustkowia

Zorzy polarnej. Jakie pomieszanie

Czasów. I miejsc. Ja tu, niespokojny

W środku kalifornijskiej wiosny, bo nie układa się całość31.

30 Cz. Miłosz, Rodzinna Europa ..., s. 39.

31 Tenże, Wiersze wszystkie, s. 951. 
Wzmiankę o ojcu znajdujemy też w wierszu Platońskie dialogi: „Zawsze pod koniec tygodnia szliśmy z ojcem do łaźni na Tatarską". Wbrew tej zapowiedzi, wzmianki o ojcu na wstępie, wiersz nie jest utworem o nim, przedstawia po prostu dość szczegółowy opis łaziennych obyczajów w międzywojennym Wilnie. Współuczestnik obrzędu i wnikliwy słuchacz, czy w tym wypadku podsłuchiwacz bywalców łaźni, stwierdza jedynie w puencie: „Ich dialogi nie zasługiwałyby na miano platońskich dialogów, ale prawie"32.

Ojciec, w odróżnieniu od matki, nie został uhonorowany jakimś osobnym, specjalnie poświęconym wierszem. Jeżeli chodzi o naśladowanie pozytywnego wzorca ze strony mężczyzn, to do tej roli bardziej nadawał się dziadek Zygmunt Kunat, który, jak wiadomo, jest prototypem Kazimierza Surkonta w Dolinie Issy, a także doczekał się poetyckiego portretu w zbiorku To, jednym z późnych tomików Miłosza. Chodzi o wiersz Mój dziadek Zygmunt Kunat, dość głęboko i szczegółowo zinterpretowany przez Małgorzatę Mikołajczak ${ }^{33}$. Pochodzący ze szlachty kalwińskiej dziadek jest w tym utworze scharakteryzowany niemal tymi samymi określeniami, jakie znamy z Doliny Issy i jakie były tam podziwiane przez małego Tomaszka:

Był uprzedzająco grzeczny dla wszystkich, wielkich i małych, bogatych i biedaków, miał dar uwagi w wysłuchiwaniu każdego. [...]

Lubili go wszyscy, Litwini, Polacy i Żydzi, miał mir u okolicznych wiosek.

Poeta podsumowuje w tym wierszu jeden z ważniejszych wątków swojej poezji, formułuje jedno z jej najistotniejszych przesłań, uświadamiając sobie: „Jak bardzo trzeba cenić prowincję i dom, i daty, i ślad minionych ludzi”"34.

To właśnie przesłanie jednocześnie tłumaczy, dlaczego w poezji Miłosza tak wiele imion, nazwisk i nazw miejscowości, dat oraz różnego rodzaju szczegółów i konkretów. Poeta stroni od wszelkiego rodzaju zawiłości, niezależnie od tego, co staje się tematem jego poezji. Ta cecha twórczości szczególnie

32 Tamże, s. 1079.

33 M. Mikołajczak, ,Jak bardzo trzeba cenić prowincje”. O (inspirujacej) autobiografii Czesława Miłosza na podstawie wiersza „,Mój dziadek Zygmunt Kunat”, [w:] Zagadnienia bilingwizmu, red. Ł. Zabielski, Seria I: Dwujęzyczni pisarze litewscy i polscy, red. A. Baranow i J. Ławski, Białystok - Vilnius 2017, s. 497-510.

34 Cz. Miłosz, Wiersze wszystkie, s. 1143. 
uwydatnia się przy poetyckim rysowaniu domu i rodziny. Zwróćmy uwagę na prostotę, na frazę, w której poezja przechodzi w prozę, bo najważniejsza jest informacja, chęć utrwalenia: „Kalifornijski wędrowiec, przechowuję talizman, zdjęcia pagórka w Świętobrości, gdzie pod dębami leżą dziadek Zygmunt Kunat, pradziadek Szymon Syruć i jego żona, Eufrozyna" ${ }^{35}$. Wspomniany tutaj pradziadek Szymon Syruć także zasłużył na poetycki konterfekt, niestety nieukończony. Tekst Pan Syruć, pisany w 2003 roku, został zamieszczony w Wierszach ostatnich. Trudno omawiać coś, co jest zaledwie „projektem wiersza", jednakże widać wyraźnie, że na kształtowanie obrazu pradziadka wpłynęły tym razem w jakimś stopniu doświadczenia własnej starości.

Podsumowując, należy stwierdzić, że obraz domu i rodziny zajmuje istotne miejsce w twórczości Czesława Miłosza. Wyeksponowaliśmy wiersze, w których ten motyw jest najbardziej oczywisty, w których jest on też często jakby częścią składową tematu „małej ojczyzny”. Słowem, jest to obraz rodziny, której poeta zawdzięcza życie, która go ukształtowała i zaopatrzyła w fundament trwałych wartości. Były one na tyle istotne i cenne, że stale się do nich odwoływał, że niejednokrotnie pomagały poecie pokonywać kłopoty i trudności, których nie brakowało w jego życiu, że nigdy i nigdzie nie zacierał swoich korzeni.

Świadomie pozostawiliśmy bez analizy obraz rodziny założonej przez poetę. Wiersze na ten temat są mniej liczne, jednakże mogłyby także stać się kiedyś podstawą do napisania drugiej odsłony niniejszego artykułu.

\section{Bibliografia}

Brzóstowicz M., Dom rodzinny w "Dolinie Issy”: obecność i wartość, „Pamiętnik Literacki" 1997, z. 2, s. 13-32.

Daujotytè V., Kvietkauskas M., Lietuviškieji Česlovo Milošo kontekstai, Lietuviu literatūros ir tautosakos institutas, Vilnius 2011.

Fiut A., „Autoportret przekorny”. Rozmowy z Czesławem Miłoszem, Kraków 2003.

Fiut A., Moment wieczny. Poezja Czesława Miłosza, Kraków 2011. 
Franaszek A., Miłosz. Biografia, Kraków 2011.

Jarzębski J., Gra w Gombrowicza, Warszawa 1982.

Ławski J., Miłosz: „Kroniki” istnienia. Sylwy, Białystok 2014.

Mikołajczak M., „Jak bardzo trzeba cenić prowincję”. O (inspirującej) autobiografii Czesława Miłosza na podstawie wiersza "Mój dziadek Zygmunt Kunat”, [w:] Zagadnienia bilingwizmu, red. Ł. Zabielski, T. I: Dwujęzyczni pisarze litewscy i polscy, red. nauk. A. Baranow i J. Ławski, Białystok-Vilnius 2017.

Miłosz Cz., Rodzinna Europa, Kraków 1994.

Miłosz Cz., Wiersze wszystkie, Kraków 2011.

Turkiewicz H., „Krajobrazy i być może duchy Litwy nigdy mnie nie opuściły”. Wyznaczniki małej ojczyzny" w poezji Czesława Miłosza, [w:] Pogranicza, cezury, zmierzchy Czesława Miłosza, red. A. Janicka, K. Korotkich, J. Ławski, Białystok 2012, s. 31-50. 